\title{
Biological data for Argas japonicus Yamaguti, Clifford and Tipton under natural conditions (Ixodoidea : Argasidae)
}

\author{
Kimito UCHIKAWA \\ Department of Parasitology, Faculty of Medicine, Shinshu Unizersity, \\ Matsumoto 390, Japan
}

Received: July 28, 1975)

\begin{abstract}
Argas japonicus Yamaguti, Clifford and Tipton wintering in 2 Delichon urbica nests were collected at Agematsu, Nagano Prefecture, Japan, on November 17, 1967. All the nymphs other than protonymphs were reared individually on chickens up to adults in the laboratory. Using the informations on the sex, retrospectively, following data were obtained.

1. The wintering population comprized 48 larvae $(8.9 \%), 146$ protonymphs $(27.0$ $\%), 215$ deutonymphs (39.7\%), 10 tritonymphs (1.8\%) and 122 adults (22.6\%).

2. The sex ratios for the deuto- and tritonymphs and for the adult did not deviate significantly from half-and-half.

3. There was a very high regression of the idiosomal width toward the indiosomal length in the nymphal and adult stages.

4. The idiosomal lengths of the protonymph, deutonymph and adult were normally distributed, respectively.

5. Smaller sized deutonymphs oftener gave rise to tritonymphs in the laboratory. The difference by potential sex in the ratio of deutonymphs that passed through the 3rd instar nymphs was nonsignificant.

6. The idiosomal length of newly emerged ticks that were fed on chickens in the laboratory was described by the regression of the length of the preceeding stages. The regression coefficient was significantly larger in the female than in the male.
\end{abstract}

Biological data obtained in the laboratory have been presented for a number of argasid ticks. The bionomics of a certain tick fed on its natural host under natural conditions is, however, presumed to differ greatly from those observed in rearing experiments carried out in the laboratory.

In Argas japonicus Yamaguti, Clifford and Tipton, the life history data under laboratory conditions were recorded in the previous paper (Uchikawa et al., 1967). Because of the lack of reliable criteria for differentiating nymphal stages, studies on natural populations did not progress so far. The present author reported also that 2 to 4 nymphal

内川公人: 信州大学医学部寄生虫学教室 ( 本市旭 3-1-1) instars occurred in A. japonicus under laboratory conditions, and that nymphs in different stages and adults that emerged from different instar nymphs were definitely separable from one another by the difference in the tarsal chaetotaxy (Uchikawa and Sato, 1968). This finding made it possible to analyze the age composition of natural tick populations and to take measurements by stage of ticks living under natural conditions.

The present study was carried out to improve knowledges on natural tick populations of $A$. japonicus further than those presented in the previous paper (Uchikawa et al., 1967). 


\section{MATERIALS and MeTHODS}

Wintering ticks were collected from 2 Delichon urbica nests taken at Agematsu, Nagano Prefecture, Japan, on November 17, 1967. The idiosomal length and width of all the ticks, excluding larvae, were measured by means of a calibrated micrometer eyepiece. Tentative later nymphs, which still included a few insecure protonymphs, were reared individually on chickens up to adults at $28^{\circ} \mathrm{C}$ and $75 \% \mathrm{RH}$. After the first moulting, the ventral half of the shed skin that included legs was mounted in gum-chloral solution on a slide, and the nymphal stage was determined by the tarsal chaetotaxy. Measurements were taken individually after every moulting untill the adult emerged. Informations on the potential sex and exact nymphal stage were used, retrospectively, for discussing the size of the tick in micrometer unit, where each unit referred to $0.0425 \mathrm{~mm}$.

Nymphs that died before feeding and that were very reluctant to feed on chickens were mounted in gum-chloral solution on a slide for determining the tarsal chaetotaxy. Ten females, including the 2 largest individuals, were sacrificed to check the number of the nymphal instars they passed through.

\section{RESULTS}

\section{The age composition and sex ratio}

Ticks examined comprised 48 larvae, 143 substantial protonymphs, 228 tentative later nymphs, including 2 individuals that died during the period between collecting and examining times, 60 males and 62 females. The 2 dead specimens were proved to be deutonymphs by the characteristic tarsal chaetotaxy. Of 226 tentative later nymphs, 223 individuals fed on chickens and moulted into successive stages. The moulted skins revealed that they comprised 3 protonymphs, 210 deutonymphs and 10 tritonymphs. The 3 tentative nymphs very reluctant to feed were sacrificed and determined as the deutonymphs by their tarsal chaetotaxy. The age composition for the population was adjusted as follows: 48 larvae, 146 protonymphs, 215
Table 1 Age composition of 541 wintering ticks of Argas japonicus and sexuality of them

\begin{tabular}{lrrrr}
\hline Stage & No. & \multicolumn{1}{c}{$\%$} & $\begin{array}{c}\text { No. } \\
\text { of male }\end{array}$ & $\%$ \\
\hline Larva & 48 & 8.9 & - & - \\
Protonymph & 146 & 27.0 & - & - \\
Deutonymph & 215 & 39.7 & 95 & $45.2^{*}$ \\
Tritonymph & 10 & 1.8 & 3 & 30.0 \\
Adult & 122 & 22.6 & 60 & 49.2 \\
Total & 541 & 100.0 & - & - \\
\hline
\end{tabular}

* The value indicates the potential sexuality, calculated on 210 individuals, excluding 5 of unknown potential sexuality from a total of 215 deutonymphs.

deutonymphs, 10 tritonymphs, 60 males and 62 females (Table 1).

Of the 10 females sacrificed for determing number of the nymphal instar they passed through, 3 individuals (the largest two and moderately sized one) were proved to be derived from tritonymphs, and the other 7 were from deutonymphs (Fig. 1C).

These data showed that a maximum number of the nymphal instars for $A$. japonicus was 3 under natural conditions.

The 210 deutonymphs fed on chickens in the laboratory gave rise to 78 males, 83 females and 49 tritonymphs. These tritonymphs fed again and moulted into 17 males and 32 females. Accordingly, the deutonymphs destined to become females were enumerated as a total of 115 , whereas those destined to become males were 95 . The 10 tritonymphs in the tentative later nymphs moulted into 3 males and 7 females. The sex ratios for the deutonymphs, tritonymphs and adults were $0.452,0.300$ and 0.492 , respectively (Table 1 ). These values did not deviate significantly from $0.500(P>0.05)$.

\section{Regression of idiosomal width toward idio- somal length}

When the idiosomal width in ocular micrometer unit of 146 protonymphs, 215 deutonymphs and 10 tritonymphs and 122 adults was plotted against the idiosomal length, the relationship between both measures was linear, respectively (Fig. $1 \mathrm{~A}-\mathrm{C}$ ). Equations calculated by the method of least 

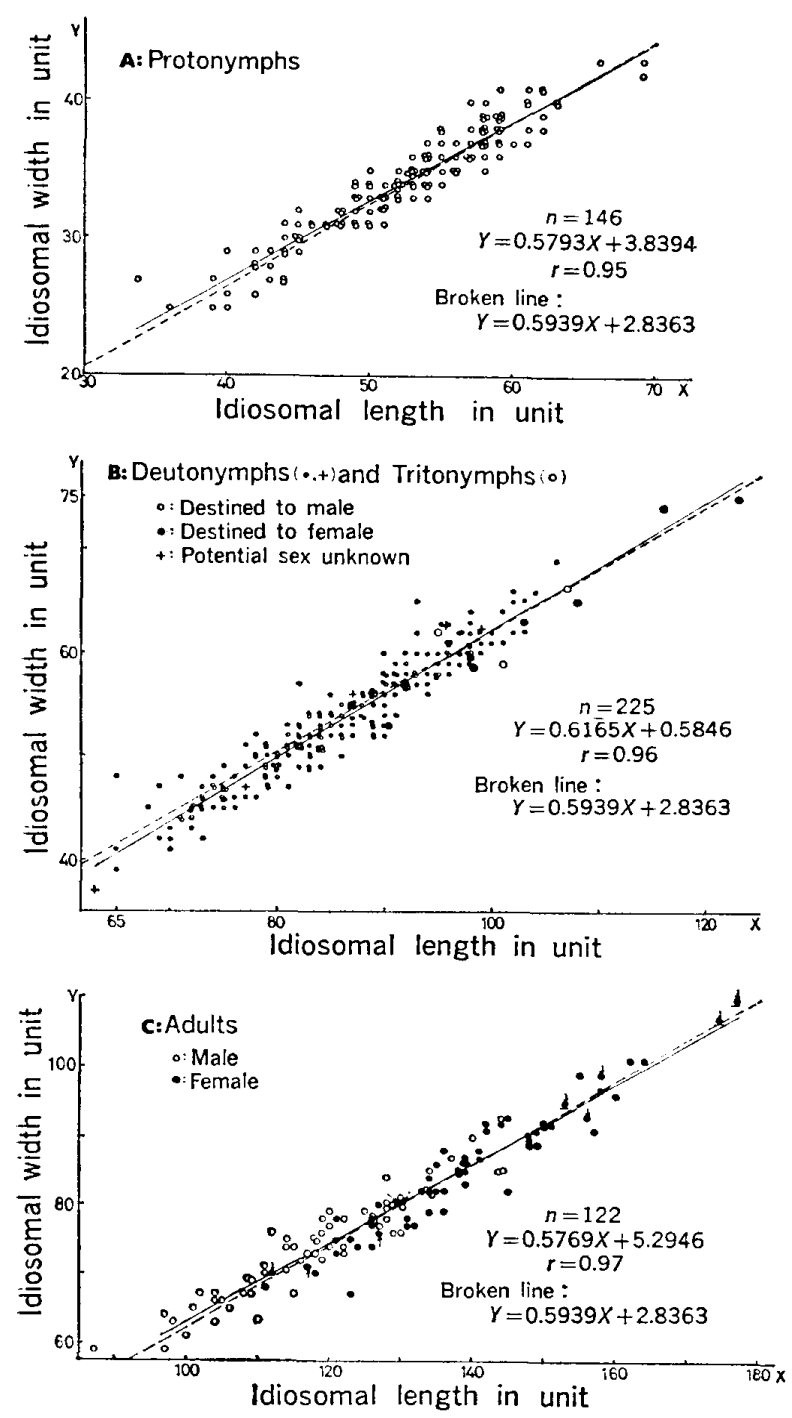

Fig. 1 Scatter diagrams of the idiosomal length and width of Argas japonicus from a wintering population

Ten arrowed examples in $\mathrm{C}$ were examined for the tarsal chaetotaxy: Underlined 3 were derived from tritonymphs and the others from deutonymphs. One unit refers to $0.0425 \mathrm{~mm}$.

squares and correlation coefficients, $r$, were as presented in each Figure. It proved that all samples, regardless of their age or sex, were distributed close to a regression line, $Y=0.5939 X+2.8363(r=0.99)$.

\section{Size of nymphal and adult ticks}

The size of the ticks was represented by the idiosomal length in unit, only by a single variable, because the width of the idiosoma could be previously predicted from the measure.

Histograms representing frequency distribu- tions of the idiosomal length in unit for the proto-, deuto- and tritonymphs and adults were given in Fig. 2A-D, respectively. Ranges of the length for deuto- and tritonymphs each overlapped in both ends with those of their preceding and succeeding stages. Difference by sex in mean length of deutonymphs was significant $(P<0.05)$, but a bimodal distribution was not observed. Such was also the case in the adult stage. Histograms for the proto- and deutonymphs and for the adult fitted to normal curves (Table 2 and Fig. $2 \mathrm{~A}, \mathrm{~B}, \mathrm{D}$ ).

Successize changes in size of nymphs reared up to adults in laboratory

The histogram representing frequency distribution of the idiosomal length for deutonymphs was drawn again in Fig. $3 \mathrm{~A}$.

This histogram was resolved into 2 parts, one for the 49 individuals that gave rise to tritonymphs (Fig. 3 B) and the other for the 161 individuals that moulted directly into adults (Fig. 3 C) in the laboratory. Both component histograms fitted better to normal distributions than synthesized one. The values of chi-square for the former two were small; $\chi^{2}=0.94$, with $d . f .=2$, in Fig. $3 \mathrm{~B}(0.750>P>0.500)$, and $\chi^{2}=2.74$ with d.f. $=5$, in Fig. $3 \mathrm{C}(0.750>P>0.500)$.

The smaller sized deutonymphs oftener gave rise to tritonymphs (Fig. $3 \mathrm{D}$. Left). Although the number of the individuals that moulted into tritonymphs was larger in the deutonymphs destined to become females than in those to males (32 vs. 17), raitos of such deutonymphs by potential sex, 32/115 and $17 / 95$, did not differ from each other significantly $(P>0.05)$.

Deutonymphs drawn in Fig. $3 \mathrm{~B}$ became adults in Fig. $3 \mathrm{~F}$ after passing through tritonymphs in Fig. $3 \mathrm{D}$, and those in Fig. $3 \mathrm{~B}$ gave rise to adults in Fig. $3 \mathrm{E}$. It was prominent that the difference by sex in the idiosomal length became pronounced with the advancement of the stage. In the adults derived from both of the deuto- and tritonymphs (Fig. $3 \mathrm{E}$ and $\mathrm{F}$ ), bimodal distributions attributed to the sexal difference were observed, though they still fitted to normal distributions. The phenomenon was explained by the difference by sex in the 


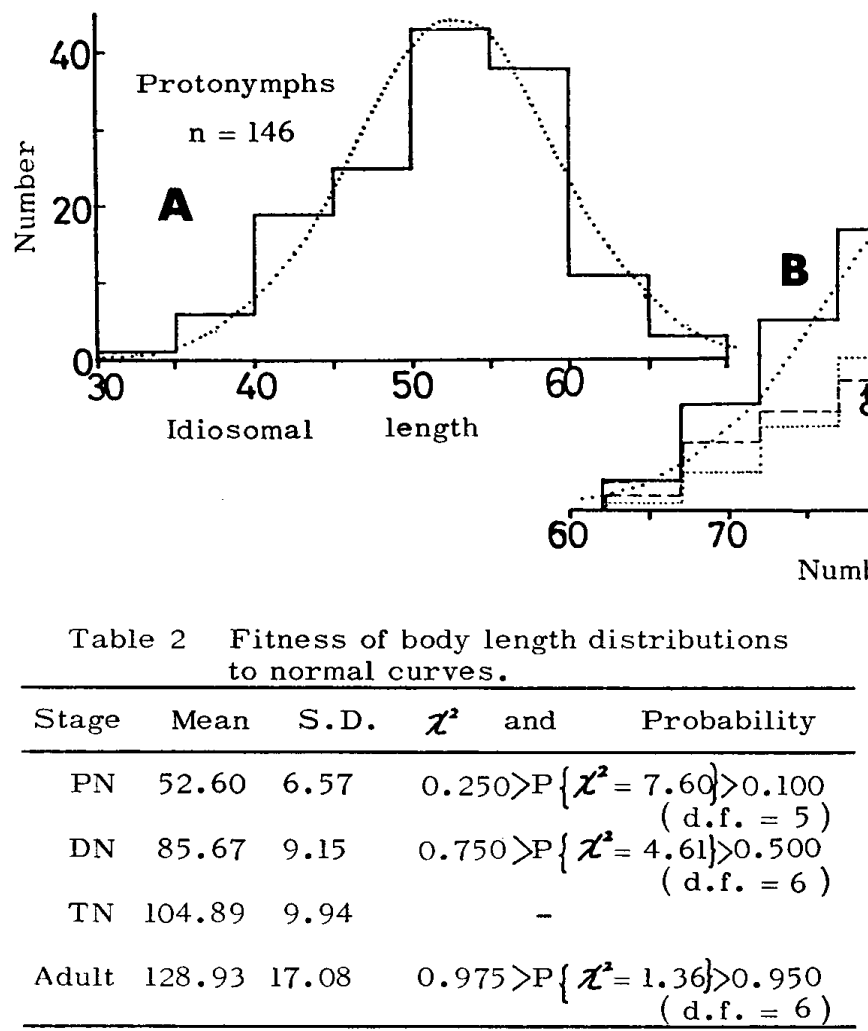

PN: Protonymph, DN: Deutonymph, TN: Tritonymph

Fig. 2 Histograms and fitted normal curves by stage of the idiosomal length of Argas japonicus from a wintering population

One unit refers to $0.0425 \mathrm{~mm}$.

growth rate per instar. When the idiosomal length of newly emerged ticks was plotted against that of unfed ticks of preceding stages, samples were distributed as in Fig. 4 , where black and open circles representing a male and a female, respectively. The relationship between the 2 measures in both sexes was linear. Two regression formulae were presented and drawn in the Figure. The $95 \%$ interval estimates of the regression coefficient $(\beta)$ were $0.8169 \leqq \beta \leqq 1.0395$ for the male ticks, and $1.2424 \leqq \beta \leqq 1.4365$ for female ticks. Both interval estimates did not overlap.

\section{Discussion}

Argasid ticks pass through multiple nymphal instars before adults emerge. The number of nymphal instars is thought to be fixed for each species, subspecies and local population. (Balashov, 1968). Although extra nymphal stages are easily introduced under laboratory conditions, it is probable that a certain species of argasid ticks performs a rather constant developmental cycle under natural conditions. In A. japonicus, it was presumed, based on the size of ticks, that there were normally 2 nymphal stages and an additional instar would appear exceptionally under natural conditions (Uchikawa et al., 1967). This was demonstrated through the analysis of the age composition of a natural tick population in the present study.

Balashov (1968) observed that incomplete engorgements resulted in inducing extra nymphal stages in Ornithodoros papillipes in contrast to the cases of ixodid ticks, in which such engorgements brought dwarf males and females. And he interpreted this as "Argasids probably have a precise, minimum nymphal size limit which permits development to sexual maturity." There was no proof of the origin of smaller sized deutonymphs, but it was clear that the appearance of an additional nymphal stage, the third stage, in A. japonicus was compensational for the deficiency in size. Balashov's " a minimum nymphal size limit" would be understood as a range of the 


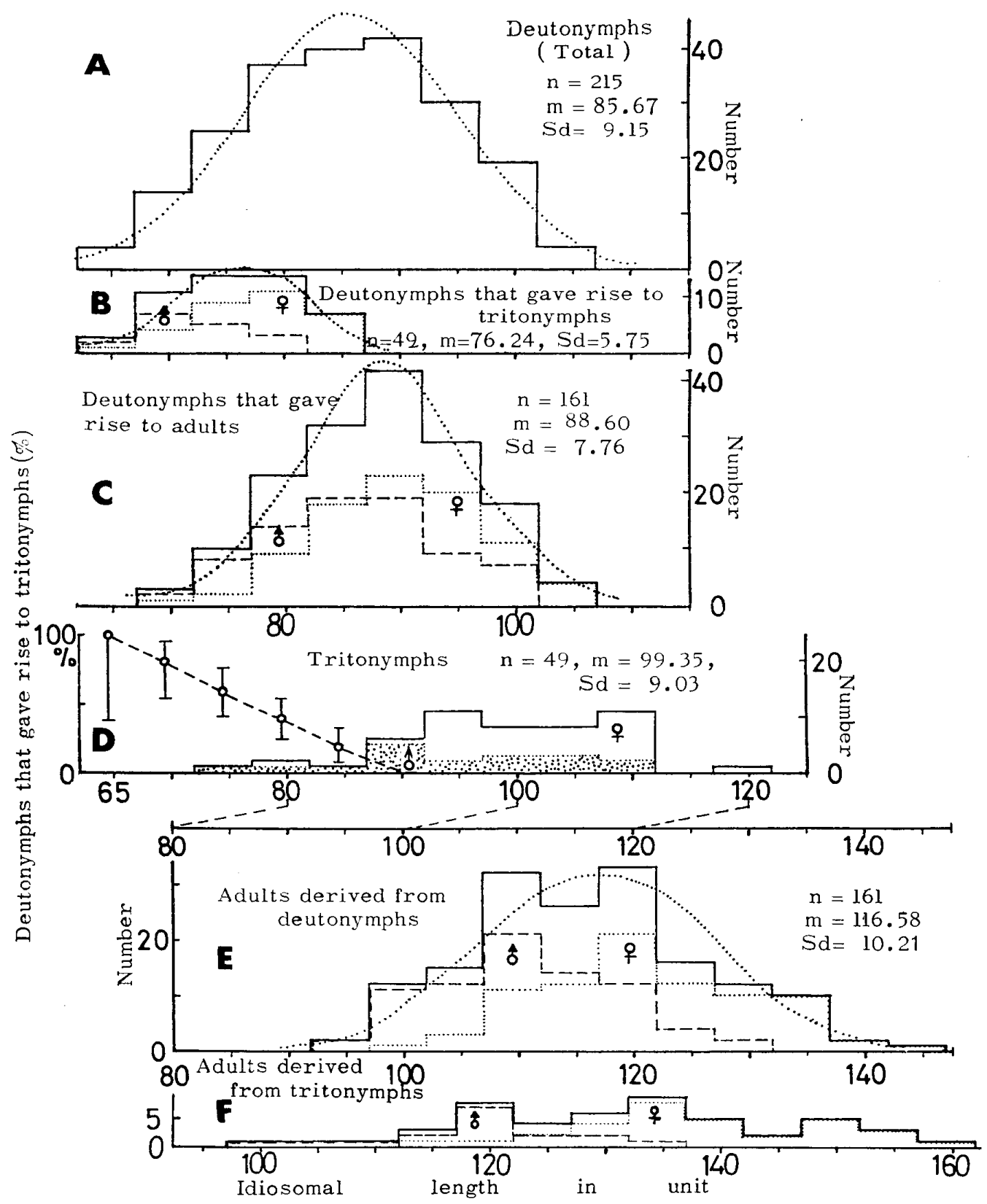

Fig. 3 Changes in size of deutonymphs with advancement of stages under laboratory conditions

One unit refers to $0.0425 \mathrm{~mm}$.

idiosomal length in unit between 67 and 87, or between 2.85 and $3.70 \mathrm{~mm}$ in the case of A. japonicus fed on the experimental hosts, the chickens. The range was almost the same as presented in the previous paper (Uchikawa et al., 1967). The difference by potential sex in the raitos of the deutonymphs that gave rise to an extra-nymphal stage was nonsignificant $(P>0.05)$, though the male ticks were reported to mature earlier than the female in Ornithodoros (Davis, 1952).

Intrastadial variations in size of immature ticks of the Ixodoidea represented by Hyalomma anatolicum anatolicum were presented by Arthur and Snow (1966). They obtained bimodal frequency distribution reflecting potential sexuality in the idiosomal length and weight of larval and nymphal stages. These intrastadial variations were attributed to the difference in the quantity of blood meals imbibed by larvae and nymphs destined to different sexes.

In A. japonicus from a natural population, such bimodal distributions of the idiosomal 


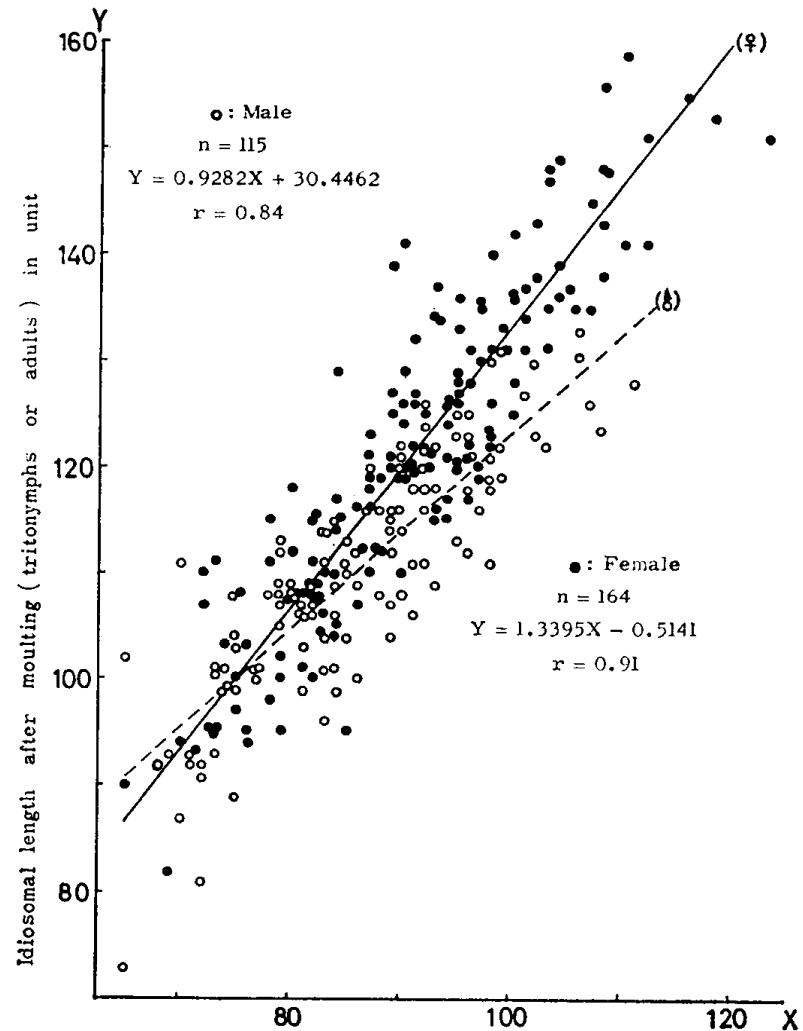

Idiosomal length before feeding (deutonymphs or tritonymphs) in unit

Fig. 4 Regressions of the idiosomal length of newly emerged ticks toward that of the preceding stages

One unit refers to $0.0425 \mathrm{~mm}$.

length were not clearly observed, though deutonymphs, tritonymphs destined to become males and adult males were significantly smaller, on average, than those destined to females and adult females, respectively.

The growth rate per moulting was significantly larger in ticks destined to become females than in those to males. This made the difference in size between the two groups by sexuality pronounced with the advancement of the stages.

The present study supported financially in part by "Nagano-ken Kagaku Shinkokai" was carried out at the Department of Public Health, Faculty of Medicine, Shinshu University, and the results were read at the 24th Annual Meeting of the
Japan Society of Sanitary Zoology (1972).

\section{REFERENCES}

Arthur, D. R. and K. Snow (1966): The significance in size in the immature stages of the Ixodoidea. Parasitology, 56 : 391-397.

Balashov, Yu. S. (1968) : Bloodsucking ticks (Ixodoidea)--Vectors of diseases of man and animals. Translation in Miscellaneous Publications of the Entomological Society of America, $8(5): 301-306$ (1972).

Davis, G. E. (1942) : Tick vectors and life cycles of ticks. Am. Assoc. Adv. Sci, Publ. No. 18: 67-76.

Uchikawa, K., A. Sato and M. Kugimoto (1967): Studies on the argasid infesting the Japanese housemartin, Delichon urbica. Med. J. Shinshu Univ., 12 : 141-155.

Uchikawa, K. and A. Sato (1968) : Tarsal chaetotaxy of Argas japonicus Yamaguti, Clifford and Tipton, 1968 (Ixodoidea: Argasidae). Jap. J. Sanit. Zool., 19 : 157-161.

\section{摘 要}

\section{自然条件下のツバメヒメダニにみられる 生物学的特性}

長野県上松町で 1967 年 11 月 17 日に採集した2個の イワツバメの巣内に棲息していたツバメヒメダニの越冬 集団を調べて, 次の知見を得た。

1. この集団は，幼虫 48 (8.9\%)，第 1 若虫 $146(27.0$ $\%)$, 第 2 若虫 $(39.7 \%)$, 第 3 若虫 $10(1.8 \%)$, 成虫 $122(22.6 \%)$ からなっていた.

2. 第 2 若虫, 第 3 若虫を成虫にまで育成した結果, 両期に抒ける性比注成虫の場合上同様に 0.5 から有意に 外れることはなかった.

3. 全発育期を通じて, 胴部長と胴部幅の間に高い回 帰性が認められた。

4. 若虫及び成虫の胴部長の頻度分布は，正規分布老 するものとみられた。

5. 第 2 若虫を室内で飼育すると，小型個体が第 3 若 虫期を経過し易く, 第 3 若虫期を経過する個体の比率に 性差のないことが判った.

6. 脱皮後の胴部長は，前令期末吸血時の胴部長の直 楾回帰によって表わされることが判明し，回帰倸数法雌 ダニにおいて雄ダニの場合より大であった。 